\title{
Amy Mills
}

\section{ULUS KIMLI ĞI IÇINDE YERELLIĞGiN YERI: KOZMOPOLIT ISTANBUL'DA AZINLIK HİKAYELER I}

Milliyetçiliğin siyasetini kapsamli bir şekilde anlamak için yerelliğin önemi göz önünde bulundurulmalıdır. İstanbul, Türkiye ve Tel Aviv, İsrail'de gerçekleştirilen bu araştırma, İstanbul'un ağırlıklı olarak bir Müslüman ve "Türk" kentine dönüştüğü 20. yüzyıl ortalarına dair mekan anlatılarına dayanmaktadır. Mekan anlatıları, ulusal geçmişe ait yorumlarin çok yönlülüklerini ortaya koyar ve bu yüzden de günün ulusal kültürel kimlik politikalarının incelenmesinde güçlü kaynak oluşturur. Bu araştırma, ulusların yaratılışında geleneksel olarak devletin tepeden-aşağıya müdahaleci rolunu inceleyen çalışmalara, sıradan insanların devletin ulus inşa etme süreçlerine verdikleri anlamları inceleyerek katkı sağlamaktadır. Yerel bir bölgeye karşı duyulan ve paylaşılan bağların çeşitli sakinler arasında ortak bir aidiyet duygusuna yol açması sebebiyle, araştırmamda yer-eksenli ilişkilerin ulusal/azınlık çerçevelerinin aşılmasına yol açabileceği sonucuna vardım. 